\title{
Language as Students' Artistic Value: Linguodidactic Dimension
}

\section{Iryna Guslenko}

Department of Theory and Practice of Translation, Kharkiv University of Humanities "People's Ukrainian Academy," Kharkiv, Ukraine

Correspondent Author: guslenkoir@gmail.com

\section{Evgeniya Myropolska}

Department of Social Sciences, Kyiv National I. K. Karpenko-Kary Theatre, Cinema and

Television University, Kyiv, Ukraine

\section{Natalia Myropolska}

Laboratory of Aesthetic Education and Art Studies, Institute of Problems of Education, National Academy of Educational Sciences of Ukraine, Kyiv, Ukraine

Received: $12 / 13 / 2020$

Accepted: 1/8/2021

Published: $2 / 24 / 2021$

\begin{abstract}
The present paper focuses on the problem of values and representation of language as an artistic value. The main objectives of the research are to specify the role of artistic values for people, represent the methodology for the integration of arts into foreign language classes, evaluate its results. The research questions of the study aimed to investigate how the experimental course contributed to students' attitude towards artistic values, the development of their language and communication skills. The outlined methodology of arts integration into foreign language classes involves teaching art terms, phraseological units about art, popular-quotations, and teaching through literary translation and dialogue of cultures. The one-term experimental integrated course of English and art classes was implemented by two secondary schools in Kyiv (Ukraine). The evaluation of the results was done with the method of qualitative research. The findings confirmed that language as an artistic value is a powerful instrument for students' personal, artistic, and cognitive development.
\end{abstract}

Keywords: artistic values, art-terms and phraseological units, dialogue of cultures, linguodidactics, literary translation

Cite as: Guslenko, I., Myropolska, E., \& Myropolska, N. (2021). Language as Students' Artistic Value: Linguodidactic Dimension. Arab World English Journal for Translation \& Literary Studies 5 (1) 248 -261. DOI: http://dx.doi.org/10.24093/awejtls/vol5no1.18 


\section{Introduction}

Values comprise different aspects of human life reflected in feelings, relationships, and interests that guide people's mental processes and behavior. This indicates the pedagogical imperative in values investigation and teaching.

Artistic values are seen as crucial factors in the progressive advance of students' emotional, sensory, and mental spheres. By introducing the works of art, students appreciate the values of other peoples and cultures, become aware of the national and global values. Through the works of art, artistic values impact the viewers' or listeners' feelings, their emotional experiences, cognitive and moral improvements.

Whereas the development of students' artistic values is considered a time-consuming process, it occurs not only in art classes. Art provides many resources for teaching languages because a language itself as a cultural phenomenon is a huge tool for teaching artistic values. That can be done through the integration of arts into foreign language classes.

The main objectives of the research are to specify the role of artistic values for people; represent the methodology for the integration of arts into foreign language classes; evaluate its results. This research is expected to give input on the implementation of the experimental course of integrated art and language classes on a long-term basis. It will promote a more profound understanding of students' native artistic values and appreciation the other cultural values.

The methodology and findings of the research are also expected to be interesting to those who investigate similar issues.

\section{Literature Review Value Dimensions}

The concept of values has been investigated by philosophers, psychologists, sociologists, and other scholars from ancient times to the present, e. g., Adler (Adler, 1956), Dilthey (Dilthey, 1995), Frese (Frese, 2015), Rokeach (Rokeach, 1973), Spengler (Spengler, 1991). Hence, the essence and nature of values are incredibly diverse. They touch upon the material and spiritual assets, social and political issues, ethical and aesthetic ones. Values can be universal and personal; they can concern the needs and interests of individuals, groups, societies, and cultures. They include the values of good, freedom, and truth; national values are linked to independence, patriotism, etc.

In Maslow's hierarchy of needs, they are regarded as lower (material) values and higher (spiritual) ones. Spiritual values embody both highly semantic ethical imperative and cultural values such as traditions, customs, and established norms, ensure the connection with the past and the like. It explains why there is no one generally accepted definition of the term. Nevertheless, they have something in common.

For instance, Dilthey (1995) connects values with the significance of life. He proves that it is values that direct the person's desires and ambitions (Dilthey, 1995).

Arab World English Journal for Translation \& Literary Studies 
From Adler's point of view (1956), the person's behavior and actions are the reflections of the personal values:

values are seen as located in man, originating in his biological needs or in his mind. Man by himself or man in the aggregate, variously referred to as group, society, culture, state, class, is seen as 'holding' values. (p.272)

Russell (1995), while analyzing the views of cynics and skeptics, emphasizes the same idea and stated, "Only subjective goods - virtue, or contentment through resignation - are secure, and these alone, therefore, will be valued by the wise man" (p. 232).

According to Pedagogical Dictionary (2001), value denotes the positive, or negative significance of real-world objects to individuals, social groups, or society that is determined not by the properties of the objects as such, but by their involvement in the sphere of human life, interests, needs, and social relations. Moral principles, ideals, attitudes, and goals become the criterion for assessing the significance of values.

Therefore, values represent a real-life space that comprises many aspects; each of them relates to life and "requests and hopes of an individual" (Tabachkovsky, 2002, p.124).

Values guide a person's mental processes and behavior because the roots of values lie in human feelings, relationships, and interests. The aesthetic categories of beauty and ugliness, the sublime and the low, good and evil do not exist by themselves, but only when a person attaches particular importance to particular objects, phenomena, and actions. The entity acquires axiological significance only when the subject favors or prefers it.

\section{Artistic Values}

While speaking about artistic values, some scholars feel skeptical, e.g., Lopes (2011) and Stecker (2012) identify them with aesthetic values. While Hanson L. (2013) offers arguments in defense of artistic values, separating them from aesthetic, ethical, and moral ones.

Artistic values refer to spiritual ones. Although they are not compulsory in their character, they can act as regulators for people due to their incentive component that shapes the individual's personality on an ethical basis. Concerning the virtues infinity and human being's multidimensionality, they become the constituent part of human life.

Artistic values reflect core life values, and they are expressly embodied in the works of art. Artistic values address the person's feelings and mind, stimulating the comprehension of certain value aspects, which in the end will or will not become the recipient's asset. Taking actions from a position of observation and assessment, incorporating values into the personality's dimensions are the constituent elements that affect people in their upbringing. However, if people do not 
perceive the inherent meanings of the works of art, they will not strive to make them the part of their hierarchy of virtues to emulate. Therefore those artistic values cannot be among their motivational preferences.

Artistic values facilitate the individual representation of a young man, so as not "to become a brick among millions of absolutely similar bricks," to become "a person, who must live his own, and not someone else life, be true to himself" (Hesse, 1990, pp. 179-181). It means to be a person who is not vulnerable to manipulations and easily overcomes the stereotypes of the community.

\section{Development of students' artistic values}

The artworks, having stood the test of time, address different people, circumstances, and epochs. They are not in the past; they never disappear; only the accents can shift. According to Spinelli (2009), creativity contains vital elements of something mysterious and unexpected. Even when the ultimate goal of the artist is clear, new opportunities, events, and methods can completely change the purpose, meaning, or outcome of the artwork (Spinelli, 2009). That gives it new dimensions or connotations suited to a particular time and space.

Sometimes the masterpieces of the past are represented as retro-works when they are studied at schools. This one-sided approach isolates artworks from today's students. There is no single approach of introduction of artistic values so that they would effectively stimulate students' emotional, sensory, and mental spheres. Still, there is a technique of emotional reinforcement in the upbringing of a personality. Its author, the Ukrainian scholar Bekh (2018), states "When we increase the strength of a certain emotion it would serve as a meaning-making function of one or another spiritual value and would give an impulse for further actions" (p. 82).

The authors assume that all masterpieces exist, metaphorically, in the grammatical category of the Continuous Tense; that is, they are ageless; they belong to both the present, past, and future. They exist in continuous time; deal with the events that began long ago. Yet they remain to be influential and relevant till now (perhaps, just for this reason, Continuous Tense is also called Progressive Tenses in association with the movement and dynamics of time and events).

A continuous connotation accentuates the informal, hidden layers of the works of art and reveals their new aspects and dimensions that meet the needs of the age; only in this way, retrodimension can gradually shift to the sphere of students' reality so that they could enjoy the masterpieces and famous works of art.

Artistic identification that comes first of all as a result of aesthetic experience and empathy allows us to live the lives of other people from different times and places; it shapes universal values, both individual and specific ones, and is a manifestation of the universe itself and the reflection of the universal integrity of life. According to Spinelli (2009), such experiences take us beyond the ordinary, beyond the framework of concepts and categories (Spinelli, 2009). 
Art classes empower students to get closer to the artistic values since they aim to form a comprehensively and harmoniously developed personality by fostering both the need in art perception and the ability to do it. Art classes focus on the identification, development, and realization of students' creative skills. The individual artistic values develop when the person learns how to perceive and experience the art when the art becomes a part of the person's inner world. As Bekh (2018) mentions the formation of new personal values is a time-consuming process. Students should have some time, and only after that, they will accept a new value. This phenomenon should be taken into account by teachers in their educational work (Bekh, 2018). While providing the opportunity to go through something previously untried, compressing and concentrating the social and historical experience of the preceding generations to the forms that should inspire personal enculturation, the art is a kind of 'data bank' of behavioral archetypes. These archetypes shape the perception of reality and culture.

In this context, the hypothetical prospects of art classes in high school (grades 10-11 of secondary schools in Ukraine) are significant. The core academic subject 'Art' will help high school students become acquainted with the spiritual continuum of other peoples and cultures, appreciate the value of something new and different, and identify their cultural roots. The study of art facilitates the comprehension of the relationship between national art/cultural heritage and art/cultural heritages of other countries. The intercultural artistic and educational environment involves the comparison of local values with the cultural heritage of other civilizations without contrasting but demonstrating their mutual complementarity. After all, each culture, with all its specific nature, is a part of humanity.

\section{Integration of arts into foreign language classes}

Living in a world where cultures communicate too tightly, we assume that the confrontation of cultures will generate sympathy for other cultures and intuitive insights in detecting differences and subtle similarities that are not immediately obvious. The mission of the humanities disciplines study and art classes, in particular, is the search for balance between the native and the foreign, or, according to the outstanding Ukrainian thinker Zenkovsky (1997), "a free combination of two different principles in their unity, without suppressing one another" (p.343).

From this viewpoint, a language as a cultural phenomenon is a huge instrument and one of the national culture's manifestations. The language learners can connect with artistic values by integrating arts into foreign language classes.

Let us consider several strategies to use for this purpose.

\section{Teaching art terms}

Learning art terms can shape students' cultural orientation, build their intercultural skills. It is necessary to know the art terms to understand art values and be able to speak about art. The problems of teaching English language learners how to speak about art were studied by Gorjian (2012), Greer (2011).

Arab World English Journal for Translation \& Literary Studies 
By teaching terms from different branches of art, the teacher should draw students' attention to the facts that terms are words or word-combinations with a specific meaning in the particular field of study (e.g., capriccio, biscuit, porcelain, theater, etc.); they are stylistically neutral; art terms are often borrowed and can be adopted by several languages, so they are international words.

Teaching terms is an excellent way to enlarge students' vocabulary and create a feeling of enjoyment in making progress in speaking a foreign language. It also broadens students' minds and develops contextual guesses. It is also useful to focus students' attention on terms etymology, their pronunciation, and spelling. For example, the words that refer to the drama are of Greek origin (e.g., chorus, dialogue, dithyramb), ballet terms are borrowed from French (e.g., pas, pas de de, grand pas), opera terms come from Italian (e.g., bel canto, solo, vero). Thus knowledge of terms facilitates the cultural involvement of the person.

\section{Teaching phraseological units about art (idioms) and famous quotations}

The acquisition of phraseological units in an English classroom setting has been profoundly studied by Liu (2008), Tsui (2004), Thyab (2016), Wood (1981), and others.

Idioms are expressions that often present a figurative, non-literal meaning. They can reflect the history, culture, and national peculiarities. That is why some do not have any translation equivalents, while the others do have functional analogs close in meaning. Idioms as a stylistic device, expand students' vocabulary and broaden their outlook, making their speech more colorful, powerful, dynamic, and creative. The use of idioms is affected by various extralinguistic, social, and psychological factors. Idioms can be successfully used as artistic expressions to impress the listeners. However, effective communication is hard if people do not understand the symbolic meaning of the idiom or the idiom is misused. That can result in language and cultural misunderstandings.

The idioms related to art can contain words for art, e.g., be no oil painting, blank canvas, drama queen, paint something with a broad brush, etc.

Famous quotations and phrases often come to English from other languages. Sometimes, people use them in the original language (e.g., Sancta simplicitas!, O tempora, o mores!, A la guerre comme à la guerre, C'est la vie, etc.). Hence, to understand and use them correctly, the students should know more about their origin, where they come from, and how their meanings have transformed.

Art idioms and famous quotations can be practiced with language learners to develop their basic skills (i.e., reading, writing, listening, and speaking) and their cultural awareness consolidation via art-related activities. Thus, learning English through idioms and famous quotations offer possibilities for intercultural and cross-cultural education through the integration of art and language teaching.

Arab World English Journal for Translation \& Literary Studies

ISSN: 2550-1542 | www.awej-tls.org 


\section{Teaching through literature and the art of literary translation}

Literature, unlike other kinds of art (e.g., music, painting, dance), is the art-form where words are the tools. That is why the incorporation of literature in language teaching is so widespread for gaining four basic skills (speaking, writing, reading, listening) and for mastering sub-skills (vocabulary, grammar, pronunciation).

The literary text of different genres, from novels and short stories to poems and song lyrics, constitutes a valuable, authentic resource for numerous reasons. One of them is cultural enrichment, which involves understanding other cultures and gaining awareness of difference. Another reason is that literary texts provide rich linguistic input, effective stimuli for students to express themselves in other languages.

Teachers exploit literary text in many ways to enrich students' vocabulary, develop comprehension skills, reinforce abilities to verbalize their thoughts (orally or in writing), and participate in discussion or debate. These techniques proved to be useful. The use of literature for translation gives an opportunity to practice acquired lexical, syntactic, semantic, pragmatic, and stylistic knowledge and develop the fifth language skill, or intercultural awareness, which according to Kramsch (1993), "must be viewed as enabling language proficiency" (p. 8).

Intrinsically translation is conceived as an act of communication when translators, who play the role of intercultural mediators, remake a text from a source language to a target language. Translation does not merely involve two languages but includes the people and cultures of both languages. If the cultural values do not overlap, the translators, in some ways, translate cultures. Due to translators, literary characters begin speaking other languages. It enriches the worldwide culture and develops native languages. For instance, an outstanding Ukrainian translator Mykola Lukash, who knew 22 languages, made an exceptional translation of Goethe's Faust (Goethe, 2013), and now the Ukrainians can enjoy the thoughts and ideas, which are still no less relevant than in the past.

The teacher should make the students realize that the essence of literary translation is not a matter of technique, it is not a photo of the text, and it is not a literal or word-for-word translation. When translating the literature, translators use their skills and talents to bridge the two cultures. They convey to readers (viewers, listeners) the closest meaning of the original text to understand and enjoy it.

Thus, literary texts used for translation develop students' language skills and intercultural awareness.

\section{Teaching through dialogue or polylogue}

Communication is a fundamental need of the human community. The word dialogue comes from two Greek words, dia and logos, where logos can be translated as word or meaning, and dia does 
not mean two; it means through. Thus, a dialogue is not restricted by two participants, either people or groups. Isaacs (1999), in his investigation of the etymology of word dialogue, concludes that:

In the most ancient meaning of the word, logos meant to gather together and suggested an intimate awareness of the relationships among things in the natural world. In that sense, logos may be best rendered in English as relationship. (p.19)

The center of the principle of participation is "the intelligence of our hearts, the freshness of our perceptions and ultimately the deep feeling of connection that we may have with others and our world" (p. 57). Consequently, dialogue involves interacting with people, their thinking together in a mutual relationship or the art of thinking together.

Through dialogue, we avoid one-dimensionality in our relationships. Because it is not merely a conversation between two people or two groups, it is the acceptance by all its participants of their respective arguments. One element integral in this process is the language that will be spoken to exchange different viewpoints.

Language is a great tool to interpret thoughts, amplify them, get into disputes with other people that can represent different cultures, so dialogue often turns into a process of communication between cultures, during which their mutual transformation takes place (Khamitov, 2017). The dialogue of cultures is based on the idea of a diverse community, where key aspects are remembering your own culture, knowing it and continuing to deepen the knowledge, creating new spiritual values, understanding the other, and learning to live together.

Increased communication between cultures, on the one hand, results in a clash of civilizations accompanied by misunderstandings and acts of intolerance. On the other hand, by meeting other cultures, people can learn how to understand them, compare, embrace the differences without labeling them as good or bad, right or wrong.

To overcome cultural barriers, we should teach students to understand how different cultures use literal and figurative meanings to express themselves, how to interpret the metaphorical language of art, which sometimes can only be intuitively guessed, foreseen.

Feinstein (1982) points out that:

Metaphor, once regarded solely as an ornamental linguistic device, is now considered to be an essential process and product of thought. The power of metaphor lies in its potential to further our understanding of the meaning of experience, which in turn defines reality. In art and in language, metaphor urges us to look beyond the literal, to generate associations, and to tap new, different, or deeper levels and meanings. (p. 45) 
Consequently, metaphor is not only essential to thought, art (including visual art) as a product of human thought can also be metaphoric by character. The difference between them is that metaphor of thought can be expressed through words, but the metaphor of visual art is expressed through images.

Through visual art in the foreign language classroom, students learn how to construct metaphoric meanings and interpret feelings translated by the artist into visual form. According to Feinstein (1985), "construction of metaphoric meaning begins by viewing the work as a whole, becoming aware of the visual attributes and nuances, and then by asking, other than obvious, what do these works suggest?" ( p. 28).

It is only by dialogue or discussion that we can unveil the symbols of works of visual art and construct meanings that expand the reality. Only through dialogue does the individual broaden the horizons of a personality and civilization - the horizons of culture; only in the dialogue each historical epoch is a living culture, and not a star that went out (Bibler, 1997). From this perspective, art can be viewed as an invitation to dialogue.

To develop the skills of understanding the artist's ideas, revealing the metaphoric language of art, and grasping how art is involved and integrated with many other human pursuits, the teachers need tools that help students articulate their values. For instance, they can find something similar and something different in the works of the artists who represent different cultures and thus reflect different life philosophies and reflections of the artist's inner self.

The authors offer to compare the works of an American artist, Georgia O'Keeffe, with paintings of an acknowledged Ukrainian artist Kateryna Bilokur (1900 - 1961), a master of primitive art who painted flowers, herbs, fruits, and whatever she could find in gardens and orchards. She was one of the greatest painters who ever emerged from Ukraine. Although both painters were contemporaries and many of their creations feature colorful and vibrant flowers, their styles and artistic manners are distinct, and it provides the matter for discussion.

To speak about arts and the peculiarities of two artists' styles, the students should revise active vocabulary so that it could help them in revealing their deep understanding of the issue. The teacher asks the students to say who the words and word combinations refer to Georgia O'Keeffe, Kateryna Bilokur, or both. The students should be ready to explain their points of view. After that, the students answer questions about the lives and creative works of both artists.

Another task is to write a dialogue essay in Google docs entitled Flower-soul after one of Kateryna Bilokur's pictures. The format of Google docs makes it possible for a group of students to write an essay together. They can give feedback to other students 'opinions, agree, or agree with them, respond, and give new ideas. It is a form of collaboration through dialogue as the art of 
thinking together; it is based on mutual participation that shows how the students can respect other people's values and points of view, or respond to students with different opinions, etc.

\section{The Study}

\section{The Sample}

The research sample includes 40 secondary school students (grade 10) learning English in two schools in Kyiv (Ukraine). The primary data for this study were collected from the students after they completed the experimental integrated course of English and art classes.

\section{Methods of Study}

The scholars assume that the measurement of aesthetic and cultural growth is complex and problematic, and very much still in the development stage (Carnwath, 2014), and the most frequent method used in the investigations of this kind is the method of qualitative research (e.g., questionnaires, classroom observations, interviews).

The 3-item questionnaire used in this study assessed how the experimental course contributed to students' language skills, attitudes towards artistic values, and communication skills.

\section{Data analysis and Study Findings}

In the first item of the questionnaire, the students were asked whether the experimental course contributed to their language skills.

Language skills

Table 1. Assessment of students' language skills development

\begin{tabular}{|l|l|l|l|}
\hline \multicolumn{2}{|l|}{ Question 1 to Item 1 } & To some extent & Not really \\
\hline \multirow{3}{*}{ Did the course contribute to your } & reading skill? & $67 \%$ & $33 \%$ \\
\cline { 2 - 4 } & & & \\
\cline { 2 - 4 } & writing skill? & $65 \%$ & $35 \%$ \\
\cline { 2 - 4 } & listening skill? & $12 \%$ & $88 \%$ \\
\cline { 2 - 4 } & speaking skill? & $80 \%$ & $20 \%$ \\
\hline
\end{tabular}

The experimental course lasted only one term, and it aimed to determine if the course would have any positive influence on the development of students' language skills. Since the course includes many tasks in speaking and discussing, $80 \%$ of the participants suggested that their speaking skills improved to some extent. Next, come reading and writing skills (67\% and 65\% correspondingly). Listening, according to the participants, is the least developed skill in the result. Only $12 \%$ of the students felt such an improvement. 
AWEJ for Translation \& Literary Studies Volume, 5 Number 1. February 2021

Language as Students' Artistic Value: Linguodidactic Guslenko, Myropolska \& Myropolska

Table 2. Impact of literary translation on language skills

\begin{tabular}{|l|l|l|l|}
\hline \multicolumn{2}{|l|}{ Question 2 to Item 1 } & To some extent & Not really \\
\hline $\begin{array}{l}\text { Did the tasks on literary translation } \\
\text { contribute to your language skills in }\end{array}$ & English? & $85 \%$ & $15 \%$ \\
\cline { 2 - 4 } & Ukrainian? & $90 \%$ & $10 \%$ \\
\hline
\end{tabular}

The participants' answers proved that translation needs a profound mastering of English as a source language and Ukrainian as a target language. Translation increases students' vocabulary, develops a sense of language, and deepens their cultural understanding.

Attitude towards artistic values

Table 3. Development of awareness of the artistic values

\begin{tabular}{|l|l|l|}
\hline Question 1 to Item 2 & To some extent & Not really \\
\hline $\begin{array}{l}\text { Did the course help raise your awareness of artistic } \\
\text { values of different cultures? }\end{array}$ & $90 \%$ & $10 \%$ \\
\hline
\end{tabular}

The main objective of the experimental course was to raise the students' awareness of the artistic values of different cultures. As a result, $90 \%$ of the participants felt the positive outcomes of the course.

Table 4. Impact of arts engagement on personal development

\begin{tabular}{|l|l|l|}
\hline Question 2 to Item 2 & To some extent & Not really \\
\hline $\begin{array}{l}\text { Do you feel the impact of arts engagement on your } \\
\text { personal development? }\end{array}$ & $80 \%$ & $20 \%$ \\
\hline
\end{tabular}

The results shown in Table 4 reveal that the participants understand the importance of arts in human life, passive and active participation in it.

\section{Communication skills}

Table 5. Development of communication skills

\begin{tabular}{|l|l|l|}
\hline Question 1 to Item 3 & To some extent & Not really \\
\hline $\begin{array}{l}\text { Did the course help develop your communication } \\
\text { skills? }\end{array}$ & $95 \%$ & $5 \%$ \\
\hline
\end{tabular}

The experimental course aimed engagement to artistic values through dialogue and polylogue; thus high priority was placed on students' communication skills. The students' answers reflect positive results. 


\section{Discussion}

The findings represented above have reflected a positive impact of the experimental course on the participants' language and communication skills; their awareness of artistic values has also improved. The course has proved to be important for students' personal development, openness, and tolerance to other cultures. It promotes the upbringing of people who are not mere consumers of art but people who feel the need for art engagement.

Classroom observations showed that learning idioms and famous quotations became a powerful instrument in increasing students' vocabulary, developing their confidence, and teaching them the language etiquette rules.

Through the students' engagement in literary translation, they become aware of overlapping and differences between the cultures. Besides increasing English vocabulary, the students also developed their native language skills when they creatively rendered stylistic devices of the text without using the clichés. In this way, the students perceived the language as an artistic value.

Teaching students through dialogue meant not only teaching the norms of communication concerning conflicting ideas but also teaching them to conduct the dialogue of cultures with the appreciation of different values. The classroom observation showed that in comparison of two or more cultures, the participants first determined the similarities between them and then found out something different. That enhanced students' skills in communication, encouraged them to have a dialogue developing their critical thinking.

\section{Conclusion}

Ultimately, this study proves that students' artistic identification occurs when the art becomes a part of their inner world, and when students are taught how to perceive and experience the art. The presented methodology investigated the prospects of incorporating art into a language class where art is used as a resource for improving four language basic skills (reading, listening, speaking, writing) and developing the fifth skill of cultural and intercultural awareness. The latter includes respect for values of other cultures and the ability to enter into a dialogue to deepen students' knowledge, create new spiritual values, and foster their understanding of the other. The results revealed the positive impact of the experimental course on the students' level of art engagement, language skills, and personal development.

The findings of the study raised concern that the presented experimental course needs pedagogical support from school authorities, development of educational programs for other age groups of students, and their implementation. 


\begin{abstract}
About the Authors
Dr. Iryna Guslenko is an Associate Professor working at the Department of Theory and Practice of Translation, Faculty of Translation and Interpreting in Kharkiv University of Humanities since 2015 after obtaining her Ph.D. in Pedagogy (2014). There are a number of publications in the field of Teaching English and Translation on the basis of Lingua-cultural Approach.
\end{abstract}

ORCID ID: https://orcid.org/0000-0003-0785-0000

Dr. Evgeniya Myropolska is an Associate Professor working at the Department of Social Sciences in the Kyiv National I. K. Karpenko-Kary Theatre, Cinema and Television University since 2006. She obtained her Ph.D. in Philosophy in 2006 in Kyiv. Her area of research interest includes aesthetic education of arts students.

ORCID ID: https://orcid.org/0000-0001-9570-5641

Dr. Natalia Myropolska is a Doctor of Educational Sciences (2003), Professor, and Senior Scientific Associate of the Laboratory of Aesthetic Education and Art Studies at the Institute of Problems of Education of the National Academy of Educational Sciences of Ukraine, Kyiv. She is an author of a number of books and monographs on the problems of aesthetic education and aesthetic aspects of written and spoken word.

ORCID ID: https://orcid.org/0000-0002-7469-5111

\title{
References
}

Adler, F. (1956). The value concept in sociology. American Journal of Sociology, 62, 272-279. Bekh, I. D. (2018). Personality on the way to spiritual values. Kyiv-Chernivtsi: Bukrek.

Bibler, V. S. (1997). On the edges of the logic of culture. Moscow: Russian phenomenological society.

Carnwath, J., Brown, A. (2014). Understanding the value and impacts of cultural experiences: a literature review. Manchester: Arts Council England.

Dilthey, W. (1995). Categories of Life. Voprosy filosofii, 10, 129-143.

Feinstein, H. (1982). Meaning and Visual Metaphor. Studies in Art Education, 23, (2), 45-55. doi:10.2307/1319679.

Feinstein, H. (1985). Art as Visual Metaphor. Art Education, 38, (4), 26-29. doi:10.2307/3192822. Frese, M. (2015). Cultural Practices, Norms, and Values. Journal of Cross-Cultural Psychology, doi: $10.1177 / 0022022115600267$.

Goethe, J. W. (2013). Faust (transl. by M. Lukash). Bucha: Vydavnytstvo Jhupanskogo.

Gorjian, H., Barazandeh E. (2012). An evaluation of the effects of art on vocabulary learning through multi-sensory modalities. Procedia Technology, 1, 345-350.

Greer, A. (2011). Teaching English Language Learners in the Art Classroom: A Survey of Approaches. Richmond: Virginia Commonwealth University, Available at https://core.ac.uk/download/pdf/51290945.pdf

Arab World English Journal for Translation \& Literary Studies 
AWEJ for Translation \& Literary Studies Volume, 5 Number 1. February 2021

Language as Students' Artistic Value: Linguodidactic

Guslenko, Myropolska \& Myropolska

Hanson, L. (2013). The Reality of Artistic Value. Philosophical Quarterly. 63, (252), 492-508. doi:10.1111/1467-9213.12026.

Hesse, G. (1990). Letters to friends. .Literary studies, 3, 177-189.

Isaacs, W. (1999). Dialogue and the art of thinking together: A pioneering approach to communicating in business and in life. New York: Currency.

Khamitov, N. et al. (2017). Philosophical anthropology: current issues: from theoretical to practical points of view. Kyiv: KNT.

Kramsch, C. (1993). Context and Culture in Language Teaching. Oxford: Oxford University Press.

Liu, D. (2008). Idioms: Description, comprehension, acquisition, and pedagogy. New York: Routledge.

Lopes, D. (2011). The myth of (non-aesthetic) artistic value. The Philosophical Quarterly, 61, (244), 518-536, Available at http://www.jstor.org/stable/23012980

Pedagogical Dictionary, (2001). Kyiv: Pedagogichna Dumka.

Rokeach, M. (1973). The nature of human values. Free Press.

Russell, B. (1967). A History of Western Philosophy: and its Connection with Political and Social Circumstances from the Earliest Times to the Present Day. New York: Simon \& Schuster.

Spengler, O (1991). The Decline of the West (abridged ed.). Oxford: Oxford University Press.

Spinelli, E. (2001). The Mirror and the Hammer: Challenges to therapeutic orthodoxy. London: Sage Publications Ltd.

Stecker, R. (2012). Artistic Value Defended. The Journal of Aesthetics and Art Criticism, 70, (4), 355362, Available at http://www.jstor.org/stable/43496530

Tabachkovsky, V. et al. (2002). Collisions of the anthropological reflection. Kyiv: Parapan.

Thyab, R. A. (2016). The necessity of idiomatic expressions to English Language learners. International Journal of English and Literature, 7, (7), 106-111 doi: 10.5897/IJEL2016.0895

Tsui, A. B. (2004). What teachers have always wanted to know - and how corpora can help. In J. Sinclair (ed.), How to Use Corpora in Language Teaching, 12, (pp. 39-61). Amsterdam: John Benjamins Publishing Company. doi: 10.1075/scl.12.06tsu

Wood, M. M. (1981). A definition of idiom. Bloomington: Indiana University Linguistics Club. Zenkovsky, V. V. (1997). Russian thinkers and Europe. Moscow: Nauka.

Arab World English Journal for Translation \& Literary Studies 